\title{
Introduktion til Det Pragmatiske Hjul - En ny tilgang til Direktiver
}

\author{
Per Durst-Andersen
}

\begin{abstract}
It will be argued that, despite their obvious anchoring in verbal communication based on linguistic signs (symbols), Directives, i.e. Requests and Offers, have more in common with gestures which primarily involve indexes and icons. It will be demonstrated that this type of speech act should be interpreted as consisting of three indexical sign types: (1) a symptom that points at the speaker and goes back in time; (2) a signal that points at the hearer and goes forward in time; and (3) a model that points at a situation and is timeless, because it can be used at any time. On this basis, a speech act process model for communicationbased problem solving is created specifically for declarative Directives.
\end{abstract}

Nøgleord: direktiver, problemløsning, symptom - signal - model, face, sætningsformer

\section{Indledning}

Hvis man betragter pragmatikkens udvikling fra sin spæde start i 1962 (jf. Austin 1962) til den dag i dag, så er der på sin vis sket rigtigt meget, men alligevel er der ikke sket nogle kvalitative spring. Nok har vi fået et nyt begrebsapparat (jf. Searle 1969, nogle 1983), et par nye måder at analysere på (jf. Grice 1975, 1978; Sperber \& Wilson 1986, 2004; Levinson 2000), og nogle teorier omkring det vigtige høflighedsbegreb (jf. Leech 1983; Brown \& Levinson 1987; Haugh 2015). Og nok har vi fået en nødvendig social-orienteret og langt mere sprogligt set detaljeret tilgang til pragmatikken gennem Conversation Analysis (jf. Sacks, Schegloff \& Jefferson 1974; Sidnell \& Stivers 2012). Men alt dette til trods er der ikke sket et afgørende ryk i vores forståelse af sprogets og selve sproghandlingens natur og væsen, hvis vi ser bort fra pragmatikkens hovedpointe: at sproget bruges til at handle med. Men hvordan og hvorfor afsender får modtager til at handle, og hvordan modtager realiserer handlingen, står vi stadigvæk uforstående overfor. Nedenfor vil jeg forsøge at besvare nogle af disse spørgsmål ved at undersøge direktiver som løsning af problemer. 


\section{Det nye grundlag}

\subsection{En ytring er ikke et symbol, men et indeks}

I det følgende vil jeg gå ud fra at en hvilken som helst ytring skal forstås som ét stort indeks og ikke som et komplekst symbol (jf. Saussure 1916; Bühler 1934). Et symbol i sig selv er en impotent størrelse der ikke kan gøre noget af sig selv. Derfor kan ord som ung eller mand der begge er rene symboler, ikke af sig selv gøre noget som helst. Men ved hjælp af et grammem kan der skabes en ytring, fx Unge mand!, der giver retning og bevægelse (se Durst-Andersen 2008, 2009b). Alle grammemer er indekser, og dermed også de ytringer som grammemerne indgår i. Hvis en ytring var et symbol, ville dette betyde at barnet måtte lære alle ytringer udenad ligesom det lærte alle ord udenad. Dette ville imidlertid tale direkte imod hvad der kaldes sprogets produktivitet, og som anses for et særkende ved sproget (se Martinet 1949; Hockett 1963; Lyons 1977: 76f; Jakobson 1968): alle sprogbrugere i et samfund kan producere ytringer der aldrig er produceret før, og på samme måde forstå helt nye ytringer, selv om de aldrig har hørt eller set dem før.

\subsection{En ytring barer mere end én illokutionar sproghandling}

På samme måde vil jeg gå ud fra at en ytring ikke bærer én illokutionær sproghandling, som fx en Invitation, en Tilladelse, en Tvang, en Trussel eller et Råd, men udmærket kan bære to og måske også tre. En Tilladelse udelukker ikke et Råd, og en Tvang udelukker ikke en Trussel. Men Tilladelse og Tvang relaterer sig begge til de betingelser som efter afsenders mening vil være tilstrækkelige til at få modtager til at gøre hvad afsender siger, kaldet Satisfaction Conditions (jf. Durst-Andersen 1995). Man kunne også sige at afsender ved hjælp af Tilladelse eller Tvang motiverer modtager. Under alle omstændigheder ligger de forud for selve realiseringen af sproghandlingen. Et Råd og en Trussel går på de betingelser som afsender selv stiller til modtager hvis denne gør eller ikke gør hvad han siger. Betingelserne går på effektueringen af selve sproghandlingen og ligger således efter dens udførelse eller ikke-udførelse. Man kunne sige at afsender her dirigerer modtager. Alt dette betyder at man sagtens kan påføre nogen Tvang og samtidig diktere en Trussel, jf. Så satter du dig ned lige nu! Med andre ord motiverer afsender modtager samtidig med at han dirigerer ham - det første er en slags madding modtager skal bide på, det andet er afsenders trumf, så han kan være nogenlunde sikker på at modtager faktisk følger hans anmodning (for yderligere om alt dette, se Durst-Andersen 1995, 2009a, 2011 a). 
Vi kan altså konkludere at nogle ytringer i hvert fald bærer to illokutionære sproghandlinger og således har to forskellige slags indhold der relaterer sig til hver sin deltager og til hver sin ende af sproghandlingen. Men jeg vil gå endnu et skridt videre. Det viser sig nemlig at Direktiver adskiller sig markant fra al anden form for verbal kommunikation. Direktiver har mange flere lighedspunkter med non-verbal kommunikation end med anden verbal kommunikation, hvilket jeg vil forsøge at illustrere nedenfor.

\subsection{En semiotisk analyse af haindtrykket}

Non-verbal kommunikation, her forstået som emblemer, dvs. intenderede gestus (cf. Rise Jensen 1997; Kendon 1995; McNeill 1992), må nødvendigvis basere sig på semiotik og kan kun forklares og beskrives gennem semiotiske begreber. Lad os tage et illustrativt eksempel som HILSE PÅ ÉN VHA. ET HÅNDTRYK (se Rise Jensen 1999).

Ved at tilbyde én - her en ven - sin hånd demonstrerer man over for vennen at man har et forslag, dvs. vennen ved nu at han er modtager af en meddelelse, en gestushandling, som han skal tage eksplicit stilling til og eventuelt reagere på. Lad os nu analysere håndtrykket i detaljen rent semiotisk - jeg går her ud fra Peirces indeksbegreb (Peirce 1953), men anvender min egen inddeling i symptom, signal og model (cf. Durst-Andersen 2008, 2009a):

- Gestushandlingen "X giver Z sin hånd" peger bagud, dvs. hånden peger via armen tilbage på $\mathrm{X}$ og fortæller på den måde at $\mathrm{X}$ har et ønske, in casu at (gen)etablere kontakten med Z, vennen. Med andre ord er udtrykket et symptom på X's følelser hvilket samtidig kan siges at være gestushandlingens udtryksfunktion (jf. Bühler 1934). Udtryksfunktionen profilerer gestushandlingens startpunkt, hvor X's arm begynder.

- Gestushandlingen "X giver Z sin hånd" peger også fremad, dvs. hånden peger på Z og fortæller på den måde at $\mathrm{X}$ har et tilbud til $\mathrm{Z}-\mathrm{Z}$ kan etablere kontakten med X. Med andre ord er udtrykket også et signal til Z om at gøre noget, dvs. tage stilling til X's tilbud. Signalet fungerer ligesom et grønt trafiklys: Du kan gå over gaden, men du behøver ikke. Dette markerer samtidig gestushandlingens appelfunktion (jf. Bühler 1934) som profilerer dens fysiske endepunkt, hvor X's hånd slutter. Vi ser således at "en udstrakt hånd" både peger tilbage og frem, og at man på den måde kan profilere den ene side eller den anden side af den udstrakte hånd. At profilere betyder således at en del af det samlede 
udtryk har sin egen betydning. Det vigtige er dog her at symptom og signal hører sammen. De kan ikke adskilles fra hinanden, og udgør således to ender af samme stykke, eller to sider af samme sag om man vil. Det betyder med andre ord at hvis man har et signal, må der nødvendigvis være et symptom. Dette er en meget vigtig pointe som spiller en stor rolle for forståelsen af Direktiver. De vil altid indeholde et signal hvad enten de manifesterer sig som en imperativ, en deklarativ eller en interrogativ, og derfor også et symptom.

- Gestushandlingen "X giver Z sin hånd" er udover at være symptom på afsenders ønske og et signal til modtager om at gøre noget også en model som modtager skal følge, hvis han accepterer afsenders tilbud om at etablere kontakten med ham (jf. Durst-Andersen 201 la: 151-153). Det betyder at modtager skal gøre nøjagtigt det samme som afsender allerede har gjort. Denne model der altså udtryksmæssigt omfatter alt fra armens startpunkt til og med håndens endepunkt, har sin egen betydning og funktion. Afsender kommunikerer derigennem at hvis modtager etablerer kontakten, så består der er en særlig relation mellem dem. På den måde får vi også Bühlers fremstillingsfunktionen i spil.

Hvis direktiver ligner non-verbal kommunikation i funktion, hvorfor skulle de så ikke også ligne hinanden i form og indhold? Ved non-verbal kommunikation handler man med andre mennesker ved hjælp af gestus, ved sproghandlinger handler man ved hjælp af sproget. Man kan invitere nogen inden for ved hjælp af en gestus eller ved hjælp af sproget, og man kan true nogen ved hjælp af en gestus eller ved hjælp af sproget. Så hvis en gestus på én og samme tid peger i tre forskellige retninger, hvorfor skulle en ytring så ikke også gøre det? Der skal under alle omstændigheder være tre ting til stede for at vi kan kommunikere non-verbalt eller verbalt: en afsender, en modtager og en situation, dvs. første person, anden person og tredje person. Hvis der er det, og det skal der være for overhovedet at kunne kalde det kommunikation, så må der være et symptom, et signal og en model, for symptomet er førstepersons-orienteret og peger tilbage på en fortidig situation, hvor X er involveret, signalet er andenpersons-orienteret og peger frem mod en fremtidig situation, hvor Z er involveret, og modellen er tredjepersons-orienteret og peger samtidig på en situation, hvor alle mulige former for $\mathrm{X}$ og $\mathrm{Z}$ kan være involveret. 


\subsection{Direktiver som problemløsning}

Ved positive direktive ytringer som fx Giv mig en pille! ønsker afsender en tilstandsændring; ved negerede ytringer som fx Giv mig ikke piller! ønsker han at verden bevares som den er. Ingen har hidtil fortalt hvornår og under hvilke betingelser afsender ønsker en forandring eller ikke ønsker en forandring. I det følgende vil jeg betragte Direktiver som en måde at løse problemer på. Det interessante er at Leech allerede i (1983) henviser til problemløsning i forbindelse med sin gennemgang af Direktiver, men ingen har hidtil arbejdet videre med tankegangen.

Man kan spørge sig selv hvad et problem egentlig er. Alle ved det, men det er ikke så let at definere det. Jeg vil dog forsøge: En tilstand opleves som et problem når den er negationen af den ønskede tilstand. Vi taler om en diskrepans mellem den faktiske og ønskede tilstand. Den faktiske tilstand opleves med andre ord som en mangeltilstand, et problem, der skal fjernes eller elimineres. Man kan også sammenligne det med en oplevet form for uligevægt mellem det reelle og det ønskede/ønskelige. Gør vi det, kan vi få problemer forankret i vores samfund idet problemer skaber uligevægt. Ifølge Habermas (1998; Finlayson 2003: 41ff) stræber et samfund altid mod ligevægt, equilibrium. Det passer samtidig meget fint ind i Habermas' ide om at hver eneste gang en succesfuld kommunikativ handling finder sted, så opnås der konsensus (det er også ligevægt) der naturligt bidrager til livsverdenen og er med til at genopbygge den. I forbindelse med en succesfuld Direktiv vil der alt andet lige være tale om konsensus mellem afsender og modtager samtidig med en genoprettelse af equilibrium i samfundet.

På den måde har vi skabt en psykologisk og social ramme for Direktiver og samtidig fået etableret en forbindelse til kulturbegrebet: det er ikke det samme der opleves som problemer i alle kulturer (tænk bare på det at være tavs i selskab med andre); ligeledes er der forskellige regler for hvordan en person/en afsender løser egne problemer ved hjælp af en anden person/ modtager og ikke mindst hvordan en person/en afsender afhjælper en andens/ modtagers problemer.

\section{Det Pragmatiske Hjul for deklarativer}

I det følgende skal jeg gennemgå en sproghandlingsprocesmodel for Direktiver som jeg har kaldt Det Pragmatiske Hjul (se figur 1). Modellen er ment som en universel model idet begreberne er så generelle at de burde kunne dække alle sprog og direktive sproghandlinger. I den givne variant (se figur 
1) har jeg dog specificeret den så den udelukkende passer på direktiver med en deklarativ sætningsform.

Modellen består af fire stationer svarende til klokken 12, kl. 9, kl. 6 og kl. 3. På Station 0 (kl. 12) markeret [+ Problem Situation] identificerer afsender et problem (som $\mathrm{fx}$ det der beskrives i scenarie nr. $1 \mathrm{i}$ afsnit 4 nedenfor) og formulerer et løsningsforslag i sine tanker. Hvis afsender nu vælger en kommunikationsbaseret problemløsning, vil han mellem Station 0 og Station 1 (kl. 9) benævne sit forslag, altså beskrive løsningen på problemet (fx Du kan tage en kopi). Ved at benævne sit forslag demonstrerer afsender sit ønske der samtidig er et symptom på hans oplevelse af situationen. Hvis vi taler specifikt om deklarativer, vil selve benævnelsen af forslaget ikke blot vise at han accepterer den ændring han foreslår (fx Du kan da tage en kopi), men han underskriver faktisk sit eget forslag og står således inde for forslaget i sin første udformning. Fra Station 1 kører afsender nu mod Station 2 (kl. 6) med sit underskrevne forslag i hånden. Undervejs er det nu afsenders opgave at frame forslaget specifikt til modtager ved at motivere ham, dvs. ved enten at fjerne eventuelle forhindringer eller ved at beskrive at der ikke er forhindringer af nogen art ( $\mathrm{fx} D u$ kan da bare tage en kopi). Når afsender når frem til Station 2, afleverer afsender et færdigt tilbud til modtager pakket ind i informationer. Selve overdragelsen af tilbuddet til modtager og det at tilbuddet kun har afsenders underskrift, fungerer begge som signaler til modtager til at tage stilling til tilbuddet. I forbindelse med overrækkelsen af tilbuddet kan afsender have en allonge til selve tilbuddet. Det bliver formuleret mellem Station 2 og Station 3 (kl. 3) hvor afsender kan tilføje betingelser for tilbuddets udførelse ( $\mathrm{fx}$ Du kan da bare tage en hurtig kopi). Her dirigerer afsender modtager. Hvis modtager accepterer tilbuddet, vil modtage skrive under på Station 3. Herefter vil han følge den model af situationen der ligger i afsenders beskrivelse af tilbuddets udførelse, og på den måde implementere forandringen mellem Station $3 \mathrm{og}$ Station 4. Når modtager når Station 4 (kl. 12), er problemet endeligt løst [- Problem Situation], og ligevægten er opnået. 


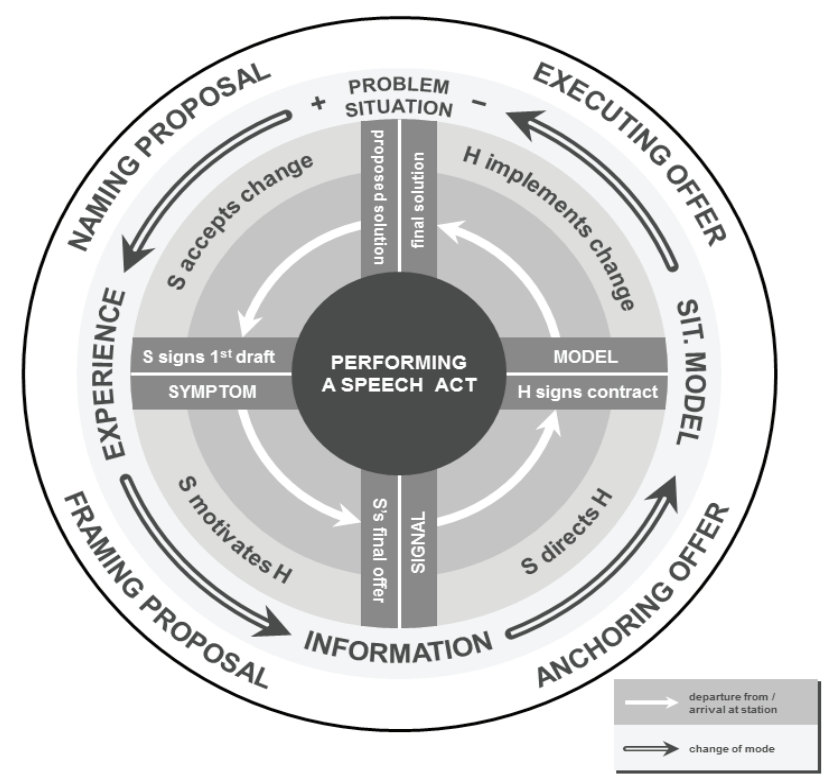

Figur 1. Det Pragmatiske Hjul specificeret for deklarativer.

Det nye ved denne model er at vi starter ude i en situation og ender samme sted. Det betyder at vi for første gang får modtager til at udføre den handling som er beskrevet i afsenders forslag. Lad os nu se på henholdsvis en typisk engelsk, dansk og kinesisk deklarativ for nærmere at kunne redegøre for modellens konkrete implementering i forbindelse med data.

\section{Kan vi se de tre indekser $i$ konkrete ytringer?}

Jeg hævder således at der altid er tre forskellige indhold til stede i en hvilken som helst ytring - og således også i en ytring der bærer en Direktiv. Disse tre indhold indgår i en særlig orden: (1) fra situation til afsender; (2) fra afsender til modtager; og (3) fra modtager til en situation, eller sagt i semiotikkens terminologi fra symptom via signal til model af en situation og derfra til den reelle situation. Jeg siger ikke at disse tre indhold nødvendigvis altid svarer til tre sproghandlinger, men jeg siger at man kan få tre sproghandlinger i én 
og samme ytring fordi der altid er tre indhold. Det fremgår nedenfor hvor scenarie nr. 1 i vores test er gengivet. ${ }^{1}$

\section{Scenario description 1: You are at work (Permission; equal; public)}

You are printing out a lot of copies, when your colleague, John, comes into the copy room with just one piece of paper in his hand. There is only one printer in the room, and you can see that John is in a hurry to use the machine, but does not like to ask you. You want to tell him that it is OK, so you say:

(1) It's OK. You can take a print, but do it quickly.

(2) Du kan da bare tage en hurtig kopi.

(3) nǔ xiān fùyìn ba.

du først kopiere $b a$

'Du kopierer først.'

\subsection{Den engelske variant}

Den engelske variant (1) er valgt fordi den illustrerer en række vigtige ting ved den prototypiske måde englændere skriver en kontrakt med modtager på, hvilket netop gøres gennem en deklarativ. For det første viser rækkefølgen af de tre ytringer hvordan afsender stille og roligt tager turen gennem Det Pragmatiske Hjul fra Station 0 til Station 3 hvor modtager tager over og alene tager resten af vejen for at mødes med afsender på Station 4 der er sammenfaldende med station 0 (se figur 1). Først viser afsender at han accepterer ændringen i situationen, ved at sige $I t$ 's $O K$. Før modtager kom ind i kopirummet, var det hele problemløst og alt åndede fred og idyl. Da modtager træder ind i rummet med kun én kopi i hånden og samtidig ser ud til at have rigtigt travlt, opstår der en ny situation og dermed et problem,

1. Data er taget fra en produktionstest som vi i The Global English Business Communication Project udførte fra 2013-2015. Testen bestod af 17 scenarier der hver især krævede en sproglig reaktion for at løse et problem. 25 personer fra henholdsvis Carlsberg i DK, England, Rusland og Kina deltog i den engelske test, mens andre 25 deltog i en tilsvarende modersmålstest i de tre sidstnævnte lande. Herudover deltog 25 studerende fra henholdsvis England, Japan og Kina i den engelske variant. 
og det er den nye situation afsender accepterer ved at sige at det er i orden. Afsenders forslag til løsning af problemet er ikke You can take a print, men You take a print. Can i You can take a print er afsenders framing af forslaget specifikt til modtageren. Her giver afsender modtager en Tilladelse til at printe, men bemærk at tilladelsen kun går på én kopi. Det er tydeligt i alle de 25 britiske besvarelser vi fik i Carlsberg England, at afsender føler at han ejer kopimaskinen, hvorfor han er nødt til at give modtager en tilladelse. Det er det samme som at fjerne en forhindring der netop muliggør bevægelse og således fungerer som et signal. Ytringen but do it quickly er den allonge som afsender vedhæfter selve tilbuddet til modtager. Den siger at modellen der skal følges, er som følger: Hvis modtager udfører tilbuddet hurtigt, så vil modtager ikke stå i gæld til ham. På den måde udgør allongen en Fritstilling (Release) af modtager der således kan være helt rolig, hvis han altså tager den ene kopi hurtigt og smertefrit for afsender. Det vigtige er med andre ord at afsenders forslag til problemløsning er You take a copy, hvilket svarer til det han formulerer i sine tanker, men forslaget bliver pakket ind i en kommunikativ pakke der giver modtager et konkret tilbud, med en tilhørende allonge - en pakke der indeholder en gave (jf. Sherry 1987; Osteen 2002).

\subsection{Den danske variant}

Den danske variant siger sådan set det samme, men i stedet for at bruge tre ytringer har den danske afsender valgt at bruge tre sproglige markører til at formidle det samme indhold. Partiklen $d a$ giver afsenders accept af den nye situation og svarer således til $I t$ 's $O K$. Partiklen bare markerer afsenders tilladelse - den betyder egentlig 'nøgen', hvorved det bliver klart at partiklen fjerner en forhindring ved at gøre vejen nøgen. Bemærk at man opstiller forhindringer hvis man negerer denne partikel: Du kan da ikke bare gå til eksamen uden at forberede dig. Partiklen bliver således et signal til modtager - et grønt lys. Da der altid er et symptom for enden af et signal, vil modtager samtidig vide at afsender ønsker den tilladte tilstand. Adjektivet hurtig $\mathrm{i}$ en hurtig kopi peger på den model der skal følges når modtager skal forankre tilbuddet i virkeligheden, hvis han altså accepterer tilbuddet. På den måde manifesterer hurtig kopi en Fritstilling af modtager i maskeret form. Det er værd at bemærke sig at rækkefølgen af partiklerne ikke kan ændres, hvilket i hvert fald ikke falsificerer hjulets indretning. Det er også værd at fremhæve at et enkelt ord i kraft af sin nærmere bestemmelse af et symbol kan få indeksikalsk karakter og dermed pege på en hel betingelse. Endnu engang konstaterer vi at kommunikation rummer en masse indekser. Afsenders forslag er her Du kan tage en kopi som adskiller sig 
fra den engelske variant. Betydningsforskellen mellem det ene og det andet er ikke stor, men det er alligevel tydeligt at det danske forslag ligesom rummer betingelsen: hvis du vil. Det ligger ikke i den engelske variant.

\subsection{Den kinesiske variant}

I den kinesiske ytring, nu xiān fùyin ba 'Du kopierer først' der faktisk blev sagt af mere end halvdelen af de 25 informanter, støder vi på den sætningsfinale partikel $b a$. Den har egentlig tre funktioner:

(4) tā shì méigóu rén ba.

han er amerikaner $b a$

'Han er nok amerikaner.'

(5) hăo ba!

godt $b a$

'Det er OK med mig!'

(6) wŏmen zǒu ba!

vi sætte sig $b a$

'Lad os sætte os ned!'

(4) er afsenders bedste bud på en beskrivelse af en situation, kaldet tredjepersons-betydningen; (5) er afsenders accept af et tilbud, kaldet førstepersonsbetydningen, og (6) er afsenders anbefaling til modtager, kaldet andenpersonsbetydningen - at give nogen en anbefaling forudsætter ikke blot at man anser det for bedste bud på en beskrivelse af situationen, men også at man selv accepterer og står bag tilbuddet til modtager. Derudover viser man også at modtager er værd at give en anbefaling, hvilket ikke er uvæsentligt. I nu xiān fuyin $b a$ 'Du kopierer først' manifesterer $b a$ alle sine tre betydninger fordi den er brugt i andenpersons-funktionen der netop forudsætter de to andre. På den måde viser afsender på én og samme tid at han skriver under på sit eget forslag om at modtager kopierer først der samtidig regnes for det bedste bud på en beskrivelse af virkeligheden, og ikke nok med det: det er også det forslag som afsender anbefaler til modtager. Anbefaling (Recommendation) er et relativt vagt signal. Men det er et signal om at acceptere det eller lade være. Der ligger ikke noget pres på den kinesiske modtager. Han kan sådan set acceptere det eller undlade at gøre det. Hvis han accepterer det, vil forslaget samtidig være en model han skal følge umiddelbart efter accepten. 
Det interessante ved de 25 kinesiske informanter er at ingen af dem, hverken i dette eller i de andre 16 scenarier vi undersøgte, italesatte en allonge, dvs. kinesere kan tilsyneladende ikke stille krav til modtager omkring tilbuddets udførelse. Dette er værd at bemærke sig. En anden ting der falder i øjnene, er at ingen af de 25 kinesere verbalt indikerede at afsender samtidig udstedte en Tilladelse. Tværtimod peger data på at de kinesiske ytringer er resultatet af en deduktion der beror på en fælles social regel - en regel der erstatter viden om hvem der ejer eller ikke ejer kopi-maskinen. I Kina er der ingen der ejer den, hvorfor der opstår et problem i det beskrevne scenario 1. For at løse den slags problemer er der tilsyneladende en konsensus om at Hvis du har ferre kopier end jeg har / Hvis du har mindre tid end jeg har, så kopierer du forst. Denne sociale regel (Rule i Peirces terminologi (Peirce 1932)) ser ud til at være anvendt, og ved at applicere denne regel på den konkrete sag: Du har ferre kopier end jeg har / Du har mindre tid end jeg har (Case i Peirces terminologi), når afsender frem til konklusionen: Du kopierer forst (Result i Peirces terminologi). På den måde kan man redegøre for hvorfor $14 \mathrm{ud}$ af de 25 kinesere netop siger det samme - de kender alle denne regel som styrer samfundet for at undgå problemer eller for lynhurtigt at løse problemer der pludseligt opstår uden nogen er skyld i dem. Da afsender kun ytrede konklusionen (Result), har vi på denne måde etableret adgang til afsenders konkrete tanker i forbindelse med løsningen af problemet i kopirummet. Stillet op i en logisk form ser de ud som følger:

(7) Social Rule: Hvis du har færre kopier end jeg har, så kopierer du først Case: $\quad$ Du har færre kopier end jeg har

Result: Du kopierer først

\section{Kan vi forklare valg af sætningsform i forbindelse med Direktiver?}

I forbindelse med Direktiver hvor et problem skal løses gennem modtager, står afsender principielt set overfor et valg mellem tre sætningsformer, nemlig imperativ, deklarativ eller interrogativ. Kan vi forklare dette valg eller begrunde det på nogen måde? Det tror jeg at vi kan. Følgende naturlige spørgsmål opstår når afsender står over for et problem: Hvor ligger løsningen på pro- 
blemet? I situationen? Hos afsender? Eller hos modtager?² Ligger løsningen i selve situationen, så viser data fra vores undersøgelse at afsender vil vælge imperativformen (her fra et andet scenarie i vores undersøgelse med britiske deltagere): Don't open the window! It is broken. Hvis afsender mener at han selv har løsningen på problemet, så vil han bruge en deklarativ som fx It's OK. You can take a copy. Hvis afsender derimod mener at det er modtager selv der har løsningen på problemer, så vil afsender bruge en interrogativ (her fra endnu et andet scenarie med britiske deltagere): Do you want me to take your bag? Dette syn forklarer på en meget enkel måde at der er et valg mellem tre sætningsformer, og samtidig hvorfor en afsender snart bruger den ene form, snart den anden og snart den tredje sådan som vores data viser. Situationerne er forskellige og tolkes forskelligt af deltagerne. Det nye syn åbner også op for en ny forståelse af face-begrebet. Normalt skelner man mellem to slags face, men jeg skelner mellem tre ansigter der i princippet er på spil i hver eneste ytring. Afsenders face er på spil, fordi han gennem sin verbale adfærd kan give et andet billede af sig selv end folk har. Modtagers face er også på spil, fordi afsender gennem sin verbale adfærd kan behandle modtager på en måde der ikke stemmer overens med modtagers selvbillede eller publikums billede. På samme måde er samfundets face også på spil idet samfundet stræber mod ligevægt, og hvis der eksisterer et problem, er der per definition ikke ligevægt. Hvis problemet løses, er samfundets face bevaret; hvis det ikke løses, taber samfundet face. Lad os se på dette ganske kort, da pladsen ikke er til mere:

- Den imperativiske sætningsform, fx Set Dem ned! eller Tal ikke så højt!, prioriterer samfundet højest ved at problemet bliver løst her og nu. Hvis afsender anvender en imperativform over for modtager, er der principielt ingen escape-mulighed for modtager med mindre modtager vil udfordre afsender. Det er til samfundets bedste idet uligevægt erstattes af ligevægt så snart uligevægten opdages af afsender. Dette gælder også potentielle problemer der kan ændre verden til det dårligere - de standses også hurtigt og effektivt med en imperativ.

- Den deklarative sætningsform, fx De kan sette Dem ned eller De behøver ikke tale så højt, prioriterer afsender højest idet han ikke tvinges til

2. Jeg er her inspireret af Pia Lauritzens analyse af spørgsmålets filosofi og struktur, jf. Pia Lauritzen (2016). Hendes arbejde er også den direkte årsag til at kinesisk nu klassificeres som et afsender-orienteret sprog. 
at bruge en form der udelukker en escape-mulighed. I forbindelse med Direktiver indeholder den deklarative sætningsform afsenders forslag til løsning af problemet - i modsætning til imperativen der løser problemet her og nu, uden nogen som helst form for forhandling. Hvis et forslag til problemløsning skal føre til problemets løsning, må det indebære at afsender tages meget alvorligt af modtager - sprogbrugerne prioriterer afsenders face højest. Ved at foreslå en problemløsning over for modtager konstaterer afsender at der er et problem, men han gennemtrumfer ikke problemets løsning. Han lader det være op til modtager at acceptere forslaget, og gør modtager det, vil afsender og modtager have en fælles kontrakt for denne ene situation.

- Den interrogative sætningsform, Vil De ikke satte Dem ned? eller De kunne vel ikke lige rakke mig min frakke?, prioriterer modtager højest idet denne er givet maksimal escape-mulighed. Til trods for at interrogativen (der i sig selv er et signal til modtager om at besvare et spørgsmål) i den pågældende situation tæller som en Direktiv (der er et signal til modtager om at reagere på det påpegede problem og således løse det), kan modtager godt vælge at læse det bogstaveligt ved $\mathrm{fx}$ at sige Egentlig ikke - Jeg foretrakker at stå op. Den interrogative sætningsform tager således modtager alvorligt ved at prioritere hans frie valg højere end såvel afsenders behov og samfundets ve og vel. Afsenders brug af et spørgsmål betyder imidlertid også at han ikke på noget tidspunkt egentlig konstaterer et problem over for modtager - han underforstår det. Modtager er således i princippet frit stillet, hvilket meget konkret kommer til udtryk i de mange negerede varianter af spørgsmål der alle markerer noget yderst hølligt. De kunne vel ikke lige rakke mig min frakke er negeret, fordi afsender i sin imagined world går ud fra at modtager $i k k e$ kan og derfor slet ikke behøver det. Der er altså tale om et helt åbent forslag hvor modtager selv kan skrive kontrakten.

Der er ingen tvivl om at imperativen er den form der hører umiddelbart til verbal problemløsning. Det er her at imperativen bruges som stimulus (signal) og modtagers handling er respons (reaktion). Men i princippet er alle ytringer i sproget stimuli der kræver respons: En deklarativ kræver stillingtagen i form af fx nikken eller rysten på hovedet; en interrogativ kræver et svar. På den måde ligger der et signal i alle ytringer uafhængigt af form. Det betyder at alle såkaldte indirekte sproghandlinger ikke er neutrale stimuli (helt i modsætning 
til Pavlovs tallerken eller klokkeringning der ikke har nogen fællesnævner og derfor er neutrale stimuli). Det eneste man således skal lære for at forstå en indirekte direktiv sproghandling er: (1) deklarativens psykologiske respons skal være fysisk i stedet; og (2) interrogativens verbale respons skal være fysisk i stedet. Det betyder med andre ord at de tre sætningsformer indgår i et hierarki hvor imperativen udgør den ubetingede stimulus og kræver den ubetingede respons, hvor deklarativen udgør den betingede stimulus, og hvor interrogativen udgør en betinget stimulus af anden grad idet den er koblet til nyforståelsen af deklarativen og ikke til imperativen.

\section{Konklusioner}

Jeg har netop forsøgt at vise at det man inden for pragmatikken kalder Direktiver samlet set hører under verbal problemløsning. Dette placerer denne sproghandlingstype i en almen sammenhæng der får inddraget mennesket i en særlig situation, situationen i en særlig kontekst og konteksten i en særlig kultur. Da den verbale form for problemløsning beskrives som modellen for non-verbal kommunikation, får vi semiotiske begreber på banen - tre forskellige former for indekser der peger hver sin vej både i forhold til deltager og $\mathrm{i}$ forhold til tidsverden. Da indekser bringer bevægelse i en kommunikationssituation, får vi forklaret dynamikken bag en Direktiv, under den og efter den, og således hvorfor modtager reagerer og hvordan han kan vide hvad han skal gøre. Alt dette forsøgte jeg at samle i Det Pragmatiske Hjul som er en universel dynamisk model der har sin grundlæggende udformning efter den imperativiske sætningsform, men som her blev gennemgået i sin deklarative variant der specificerer symptom, signal og model som henholdsvis afsenders forslag og accept af eget forslag, som hans tilbud til modtager, og som modtagers accept af tilbud med allonge. Det viste sig at det var muligt at forklare det der ligger til grund for Direktiver i de tre sprog, engelsk, dansk og kinesisk, men samtidig også at forklare hvorved de adskiller sig fra hinanden. Her ligger engelsk og dansk tæt på hinanden i tankegang, men har forskellige sproglige indpakningsmuligheder, mens kinesisk adskiller sig i betydelig grad fra engelsk og dansk. Det kan nu forklares ved at sige at kinesere helt generelt prioriterer afsenders face, mens engelsk og dansk egentlig rummer alle face-prioriteringer. 


\section{Henvisninger}

Austin, J.L. (1962). How to do things with words. Oxford: Oxford University Press. Brown, P. \& S.C. Levinson (1987). Politeness: Some universals in language usage. Cambridge: Cambridge University Press.

Bühler, K. (1934). Sprachtheorie. Die Darstellungsfunktion der Sprache. Stuttgart: Gustav Fischer Verlag.

Durst-Andersen, P. (1995). Imperative frames and modality. Direct vs. indirect speech acts in English, Danish and Russian, Linguistics and Philosophy 18, 611-653.

Durst-Andersen, P. (2008). Linguistics as semiotics. Saussure and Bühler revisited, Signs 2, 1-29.

Durst-Andersen, P. (2009a). Imperative frames and the psychology of indirect speech acts, iJ. Zlatev et al. (red.) Studies in language and cognition. Cambridge: Cambridge Scholars Publishing, 317-334.

Durst-Andersen, P. (2009b). The grammar of linguistic semiotics. Reading Peirce in a modern linguistic light, Cybernetics \& Human Knowing 16(3/4), 38-79.

Durst-Andersen, P. (2011). Linguistic Supertypes. A Cognitive-Semiotic Theory of Human Communication. Berlin/New York: De Gruyter Mouton.

Finlayson, J.G. (2005). Habermas: A very short introduction. Oxford: Oxford University Press.

Grice, H.P. (1975). Logic and conversation, i P. Cole \& J.L. Morgan (red.) Speech acts (Syntax and Semantics 9). New York: Academic Press, 113-127. Grice, H.P. (1978). Further notes on logic and conversation, i P. Cole (red.) Pragmatics (Syntax and Semantics 9). New York: Academic Press, 113-127. Habermas, J. (1998). On the pragmatics of communication. Cambridge: Policy Press. Haugh, M. (2015). Im/Politeness implicatures. Berlin/Munich/Boston: De Gruyter Mouton.

Hockett, C.F. (1963). The problem of universals in language, iJ.H. Greenberg (red.) Universals in language. Cambridge, Mass.: MIT Press, 1-22.

Jakobson, R. (1968). Language in relation to other communication systems, Selected Writings II, 797-708. The Hague-Paris: Mouton 1971.

Jensen, M.R. (1999). Strukturen i russiske gestus: En semiotisk, semantisk og pragmatisk analyse. København: Handelshøjskolen.

Kendon, A. (1995). Gestures as illocutionary and discourse structure markers in Southern Italian conversation, fournal of Pragmatics 23, 247-279.

Lauritzen, P. (2016). Sporgsmål - Mellem identitet og differens. Århus: Århus Universitetsforlag. 
Leech, G. (1983). The principles of pragmatics. London: Longman.

Levinson, S. (2000). Presumptive meanings. The theory of Generalized Conversational Implicatures. Cambridge, MA: The MIT Press.

Lyons, J. (1977). Semantics. Vol. 1. Cambridge: Cambridge University Press. Martinet, A. (1949). La double articulation linguistique, Travaux du Cercle Linguitique de Copenhague 5, 30-37.

McNeill, D. (1992). Hand and mind. What gestures reveal about thought. Chicago: University of Chicago Press.

Osteen, M. (2002). The question of the gift: Essays across disciplines. New York: Routledge.

Peirce, C.S. (1932). Elements of logic. Collected papers of Charles Sanders Peirce, red. af Ch. Hartshorne and P. Weiss, Vol. II. Cambridge: Cambridge University Press.

Peirce, C.S. (1953). Charles S. Peirce's letters to Lady Welby, red. af I. Leib. New Haven: Yale University Press.

Sacks, H, E.A. Schegloff \& G. Jefferson (1974). A simplest systematics for the organization of turn-taking for conversation, Language 50, 696-735.

Saussure, F. de. (1916). Cours de linguistique générale. Paris: Payot.

Searle,J.R. (1969). Speech acts: An essay in the philosophy of language. Cambridge: Cambridge University Press.

Searle, J.R. (1983). Intentionality. An essay in the philosophy of mind. Cambridge: Cambridge University Press.

Sherry, J.E. (1983). Gift giving in anthropological perspective, Fournal of Consumer Research 10, 157-168.

Sidnell, J. \& T. Stivers (2012) (red.). The handbook of conversation analysis. London: Wiley-Blackwell.

Sperber, D. \& D. Wilson (1986). Relevance. Communication and cognition. Oxford: Basil Blackwell.

Sperber, D. \& D. Wilson (2004). Relevance theory. I L.R. Horn \& G. Ward (red.) The handbook of pragmatics. Oxford: Blackwell, 607-632. 